\title{
Investigation of the Agricultural Status of Rural Areas within the Boundaries of Istanbul Metropolitan Municipality
}

\author{
Merve Birinci ${ }^{1 *}$, Leyla Suri ${ }^{2}$ \\ 1* Istanbul Commerce University, Faculty of Science, Department of Urban Systems and Transport Management, İstanbul, Türkiye, (ORCID: 0000-0001-5960-3496), \\ merve.birinci@istanbulticaret.edu.tr \\ 22 Istanbul Commerce University, Faculty of Architecture and Design, Department of Architecture, Istanbul, Turkey (ORCID: 0000-0002-3225-1221), \\ 1suri@ticaret.edu.tr
}

(First received 18 May 2021 and in final form 20 November 2021)

(DOI: $10.31590 /$ ejosat.939141)

ATIF/REFERENCE: Birinci, M., Suri, L. (2021). Investigation of the Agricultural Status of Rural Areas within the Boundaries of Istanbul Metropolitan Municipality. European Journal of Science and Technology, (27), 1018-1031.

\begin{abstract}
Since land, one of the natural life resources, is a scarce resource, it should be evaluated based on its potential. In cities with a rapidly growing population, residential areas tend to expand into agricultural areas that have the potential to feed the urban population. It is observed that the expansion activities gained momentum as the borders of metropolitan municipalities are expanded to the provincial borders. Metropolitan municipalities were first expanded to the provincial border in Istanbul and Kocaeli in accordance with the 2004 Law on Metropolitan Municipalities. With the amendment to the Law numbered 6360 \& enacted in 2012, all metropolitan municipalities were expanded to the provincial borders, the jurisdiction of the municipalities was expanded, and the status of rural areas was changed with the execution of the law. Villages were transformed into neighborhood's and became natural extensions of cities. In this study, the urban population and average production values within the provincial borders of Istanbul were examined together, and the availability of agricultural areas, the effects and benefits of meeting the food needs in the city were examined. Thus, the rural areas within the boundaries of the metropolitan municipality; It has been tried to emphasize that making a land management plan taking into account the existence of agricultural land and meeting food production from the close vicinity of the city as much as possible have a multifaceted effect on the sustainability of natural resources.
\end{abstract}

Keywords: Istanbul Metropolitan Municipality, rural area, rural neighborhood, agriculture.

\section{İstanbul Büyükșehir Belediye Sınırlarında Kalan Kırsal Alanların Tarımsal Durumunun İncelenmesi}

$\ddot{\mathbf{O z}}$

Doğal yaşam kaynaklarından biri olan toprak, kıt bir kaynak olması nedeniyle potansiyelleri doğrultusunda değerlendirilmelidir. Nüfusu hızla artan kentlerde yerleşim alanları kentte yaşayan insanları besleme potansiyeli olan tarım alanlarına doğru genişleme eğilimindedir. Genişleme faaliyetlerinin, büyükşehir belediyeleri sınırlarının il sınırlarına dayandırılması ile hız kazandığı görülmektedir. Büyükşehir belediyeleri ilk olarak 2004 yılında çıkarılan Büyükşehir Belediyesi Kanunu kapsamında İstanbul ve Kocaeli ilinde il sınırına genişletilmiştir. 2012 yılında çıkarılan 6360 sayılı yasadaki değişiklikle bütün büyükşehir belediyeleri il sınırlarına dayandırılmış, belediyelerin yetki alanları genişletilmiş ayrıca yasa uygulamaya geçirildiğinde kırsal karakterde olan alanlar statü değiştirmiştir. Köyler mahalle konumuna dönüştürülerek kentlerin doğal uzantıları niteliği kazanmıştır. Bu çalışmada İstanbul il sınırları içinde kent nüfusu ve ortalama üretim değerleri birlikte irdelenerek yasa kapsamında statüsü değişen ancak halen tarım karakterini koruyan kırsal karakterdeki alanların tarıma elverişli olma durumları, kent içinde gıda ihtiyaçlarının karşılanmalarına etkileri ve yararları incelenmiştir. Böylelikle, büyükşehir belediyesi sınırları içinde kalan kırsal alanların; tarımsal arazi varlığının dikkate alınarak arazi yönetim planı yapılması ve gıda üretiminin mümkün olduğu kadar kentin yakın çevresinden karşılanmasının doğal kaynakların sürdürülebilirliği üzerinde çok yönlü etkisinin olduğu vurgulanmaya çalışılmıştır.

Anahtar Kelimeler: İstanbul Büyükşehir Belediyesi, kırsal alan, kırsal mahalle, tarım.

\footnotetext{
* Sorumlu Yazar: merve_birinci91@hotmail.com
} 


\section{Introduction}

The global population has been increasing rapidly and the majority of people live in metropolitan cities. While the total world population was 2.54 billion in 1950, it became 7.63 billion in 2018 and 7.794 billion in 2020 (Url-1). According to the official United Nations World Urbanization Prospects: The 2018 Revision report on urban and rural populations, globally, approximately $30 \%$ of the world's population in 1950 and $55 \%$ in 2018 resided in urban areas. In 2018, the urban population was 4.22 billion $(55.3 \%)$ and the rural population was 3.41 billion (44.7\%). It is estimated that this rate will be $68 \%$ in 2050 (United Nations, 2019).

Turkish Statistical Institute (TURKSTAT) considers the population living in provincial and district centers as urban population, and the population of other settlements as rural population. In a study examining the change in the rural population in Turkey between 1980 and 2012, based on TURKSTAT criteria and data, the rural population comprised $76 \%$ of the total population in 1927 . This ratio did not change much until 1950. However, people migrated from rural areas into metropolitan cities with the industrial activities across the country after 1950 thus, cities began to change and grow. Especially in the 12-year period between 2000 and 2012, the rural population decreased rapidly, and the rural population, which was approximately 24 million, decreased to 17 million. According to 2012 data, the rural population constitutes approximately $23 \%$ of the country's population. The rate of rural population living in towns and villages decreased to 7\% in 2019 (TURKSTAT, 2020a). Many factors such as the establishment of new provinces and districts and the expansion of municipal borders, the mechanization of agriculture, the continuous division of agricultural lands into small units by inheritance, and the migration movements of cities due to business, education and health opportunities have affected the change in the total rural population of our country and the rural population of the provinces. In addition, the median age in rural settlements has become quite high compared to the past. The decrease in the rural population also means a decrease in agricultural and animal production (Yilmaz, 2019).

Cities need sustainable natural resources to feed their populations with healthy food. Rural areas with high agricultural productivity located in the cities are vital in satisfying this need and should be evaluated based on their potential.

In 2019, global farmland area was 4.8 billion ha, down $3 \%$ or 0.13 billion hectares (ha) from 2000. Approximately 2/3 (3.2 billion ha) of agricultural land was used as permanent meadows and pastures, and 1/3 (1.6 billion ha) was used as cultivated land. Between 2000 and 2019, agricultural land decreased by 127 million hectares. Although agricultural land has decreased since 2000 , it increased by an average of $0.1 \%$ per year during the 1961-2019 period, with a significant expansion until the 1990s. The regional distribution of global cultivated land area has changed little from 2000 to 2019, with Asia having the largest share of global cropland in $2019(38 \%)$, followed by the Americas (24\%), Europe (19\%), Africa (18\%) and Oceania $(2 \%)$. Nonetheless, there were differences in cropland expansion in different regions during this period - Oceania and Africa both had rapid growth in arable land area $(24 \%$ and $20 \%$, respectively), while Asia showed more moderate growth (5\%). In 2019, $12 \%$ of global permanent meadows and pastures e-ISSN: 2148-2683 belonged to China, $10 \%$ to Australia and $8 \%$ to the United States of America. In the same year, India (11\%), the United States of America (10\%) and China (9\%) had the largest shares in global cultivated areas. Extensive grassland versus croplands in agricultural land may indicate intensive livestock practices as opposed to harvesting crops.

Cropland area per capita decreased in all regions between 2000 and 2019 as population increased faster than cropland. The world average declined by $17 \%$ to 0.20 ha per capita in 2019 ; the decrease was the largest in Africa (-26\%, to 0.21 ha per capita), followed by the Americas ( $-18 \%$, to 0.36 ha per capita), Asia ($15 \%$, to 0.13 ha per capita), Europe (-8\%, to 0.39 ha per capita) and Oceania (-7\%, to 0.79 ha per capita) (Figure 1). Against this backdrop, the increase in agricultural production over the same period indicates higher efficiency in feeding the population with limited land resources. The countries with the highest cropland area per capita are Kazakhstan, Australia and Canada, due to vast areas of land available over sparsely populated areas. Other reasons for high values include the intense use of agricultural inputs over cropland and dependencies on agricultural imports or food aid (FAO, 2021).

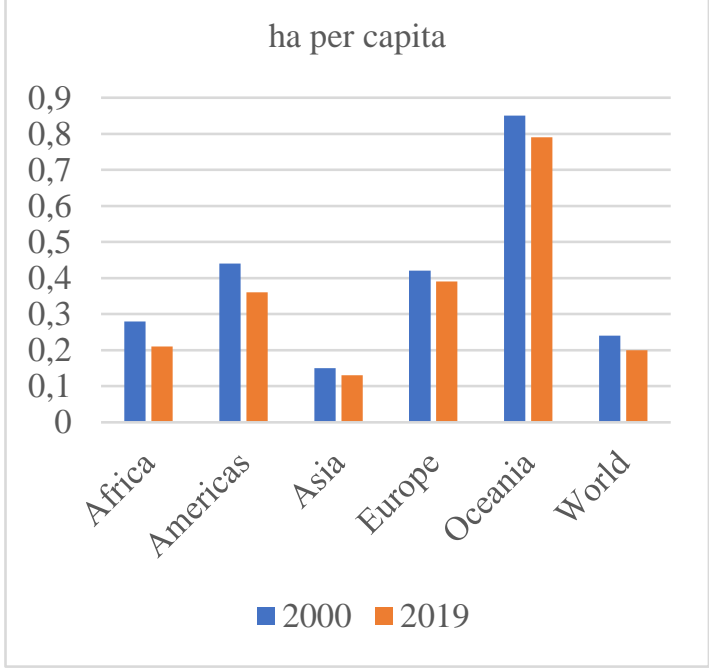
2021)

Figure. 1. Cropland Area Per Capita By Region (FAO,

According to the use of agricultural lands in Turkey in 2019 , 14,617 thousand hectares are permanent meadows and pastures, and 23,099 thousand hectares are cultivated lands. Arable land per capita (ha) decreased from 0.42 to 0.28 between 2000 and 2019 (FAO, 2021).

The concept of rural area is handled with different parameters in different countries, it is a very comprehensive concept that countries are still working on. In recent years, environmental problems encountered in densely populated settlements have caused disturbance of the natural balance considerably revealed the importance of rural areas. In addition, epidemics in the world have shown how important it is to provide sufficient food production and easy access to food.

The share of employment in agriculture, forestry and fishing declined globally by about 13 percentage points between 2000 and 2020 , to $27.4 \%$. Yet, agriculture remains the second largest source of employment worldwide after the services sector. A decline in the share of the agricultural sector is usually linked to growing income levels, which explains the drop in the share of employment in agriculture across all regions and nearly all the

1019 
countries. The COVID-19 pandemic broke this overall declining trend: while employment dropped in all sectors due to the COVID-19 restrictions, resulting in an increase of the share of agricultural employment in all regions except Europe between 2019 and 2020. The lowest share of employment in agriculture was observed in Europe in 2020, where only $5.2 \%$ of the employed population had a job in agriculture. The highest share was observed in Africa with $49.5 \%$ of the total employed population (FAO, 2021).

In the last 5 years, the number of people working in the agricultural sector in Turkey decreased by $14 \%$ to $4,716,000$ people. In Turkey, the agricultural sector has a $17.9 \%$ share among other sectors (TURKSTAT, 2021).

Various rural areas emerge in cities as a result of natural processes and human interventions that have distinct sociocultural characteristics and where activities such as agriculture, forestry, recreation are carried out (Urgenc, 2000). The natural and sociocultural elements within the scope of rural areas are shown in Figure 2.

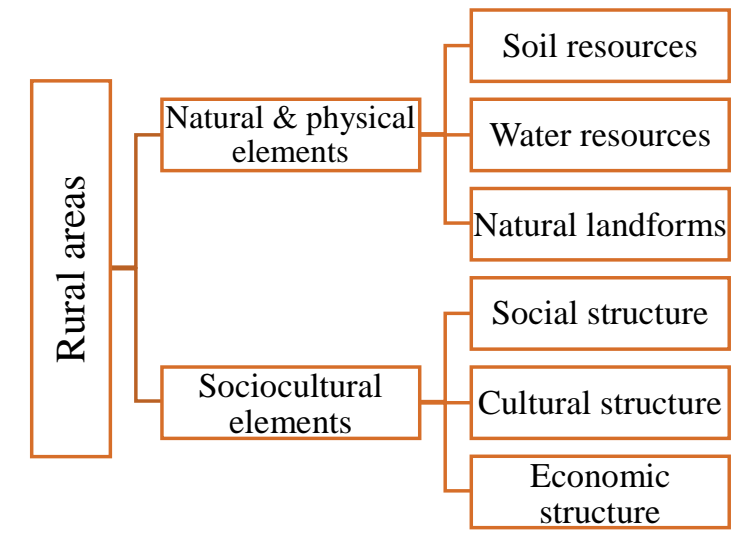

Figure. 2. Rural Area Elements (created based on Urgenc, 2000.)

Through their soil and water resources, agricultural lands in rural areas provide a source of economic livelihood for farmers and meet the food needs of the city.

According to The State of Food Security and Nutrition in the World (2019), it is estimated that more than 2 billion people do not have regular access to safe, nutritious, sufficient food. The number of undernourished people has been on the rise since 2015 (FAO, 2019). Hunger is on the rise, with almost 770 million people undernourished in 2020, 118 million more than in 2019. While most of the undernourished people live in Asia, Africa has reached the peak of malnutrition (FAO, 2021). Therefore, it is extremely important to use soil resources that can meet the food need and cannot be recovered once lost.

In Turkey, as in other countries, urban administrative units can cover rural areas and show rural-oriented characteristics in terms of population structure, land use and economic structure.

New legal arrangements are introduced to ensure that services can be provided from a single center in a more regular manner and without any confusion about authority in the management system of metropolitan cities that have an increasing population across the country. Accordingly, in 2004, Istanbul and Kocaeli were selected as pilot regions, their jurisdictions were expanded to the provincial border and this practice was intended to be extended for the integrity and efficiency of services. In accordance with the Law No. 6360 that was promulgated on 06/12/2012 but where some articles were enacted after the local elections in Turkey held on 30/03/2014, the borders of all metropolitan cities were expanded to the provincial borders and legal entity status of villages and towns were abolished.

Changing the status of all villages within the boundaries of metropolitan municipalities to neighborhood also bring the expectations of evaluating villages as rural areas. This transformation of villages will increase the misuse of agricultural lands may cause the destruction of fertile agricultural lands, losing the opportunity to benefit from lands in line with their functions, so complete loss of natural resources. It is thought that food production in rural areas will be adversely affected and create problems on livelihoods. One of the most important objectives of the study is to investigate the potentials in the specified areas.

Thus, in connection with the rural areas located within the boundaries of the metropolitan municipality, it is important to:

- Prepare a land management plan taking into account the agricultural land assets,

- Emphasize the multi-faceted impact of producing food from the immediate surroundings of the city to the full extent possible on the sustainability of natural resources.

In this research, determining the existing agricultural potentials of rural settlements that have gained rural neighborhood status within the borders of Istanbul Province, which was chosen as a field study, and determining the approximate production information that can be met with the related analyzes gives the original value of the research.

\section{Material and Method}

The study consists of three stages. In the first stage; definitions of the concept of rural area were made by taking the existing laws and practices. In this context, the data of various ministries, especially the Ministry of Agriculture and Forestry (TOB), the activity reports of the Istanbul Metropolitan Municipality (IMM), and the strategic plans of the studies were examined. The rural area legislation has been explained in detail through the administrative structure of the concepts explained by the literature review.

In the second stage, the development of the municipal structure is focused on the formation of metropolitan municipalities. The change of metropolitan municipality borders over the provincial borders of Istanbul has been examined.

In the third stage, according to the current definition of rural area, rural area boundaries in the studied sample area; It was formed based on the provincial borders of Istanbul. In this context, it provides explanatory information about agricultural data and populations of rural areas, based on the research conducted by IMM in 2017, regarding villages and towns that were administratively reclassified as rural neighborhoods. TOB 2019 Istanbul province land use data and crop production data were used. In line with these data, the plant production areas and quantities used are revealed. The population of rural neighborhoods, aging and agricultural productivity trends were examined through the IMM 2017 land use class map and analysis. For a more detailed classification of agricultural lands, the proportional distribution and amounts of AKK classes are given by using the IMM 2009 Land Use Capability (AKK)

1020 
Classes Map data. According to these data, the current arable land classes (I-IV) were calculated, and when these agricultural lands were evaluated, it was tried to determine the amount of agricultural production on rural areas in the metropolitan area.

The findings show results regarding the population that will feed the city of Istanbul. Calculations were made based on the above-mentioned land use data, 2018 population, TOB fruit and vegetable production data, and average consumption values obtained from IMM, and assumptions were made regarding the potential population.

\subsection{Concept of Rural Area}

The definition of rural area was discussed by researchers over the years there is no generally accepted common definition. (Ilbery, 1998). Studies reveal that further analysis is required on the definition of rural area (Cloke \& Park, 1985). In the first planning studies of England in the 1970s, the concept of green infrastructure (Natural England) emerged as an expression of the holistic approach between urban and rural (Tuna, 2021).

The most common example of defining the rural area is "An Index of Rurality for England and Wales" conducted by Cloke in 1977. This classification system has been recognized and used by the Department of the Environment (Halfacree, 1993).

Population size and density, the predominant type of economic activity, conformity with legal and administrative status, as well as specific services and facilities are prominent criteria to define rural and urban areas. In many Latin American countries, a population threshold of 2000 or 2500 is used to define urban areas. In South Asian countries-Pakistan, Sri Lanka, Nepal-areas having administrative institutes (municipalities, councils, committees) are declared as urban. Moreover, many African countries define urban with respect to administrative, demographic, and infrastructure characteristics. Consequently, low population and housing density, high dependence on natural resources for livelihood, limited infrastructure, and social services can characterize rural areas (Jamshed et al. 2020).

Different criteria are used in our country for defining rural areas, and demographic structure takes priority for geographers, social structure takes priority for sociologists and economic and administrative structure takes priority in the legal definition (Cetiner, 1980).

When the Rural Development Plans are examined, the first report where the concepts of "rural area" "agricultural area" and "rural development" "agricultural development" are stated to be different is the Eighth Five-Year Rural Development Report of the Specialization Commission. In this report, the concept of "rural area" which is deemed appropriate to be described as "spaces outside of urban settlements" is defined as space with descriptive concrete-objective elements. In Turkey, rural area is defined as "spatial size where individuals who cannot benefit from social security (job opportunities, insurance, pension, education, health and cultural activities) sufficiently constitute the majority and which covers provinces other than metropolitan settlements, districts, villages, hamlets within the increased number of provinces, i.e., 81 (DPT, 2000).

The Eleventh Rural Development Report of Special Commission Report emphasizes that shaping the definition of rural area based on a single factor is not adequate; however, a new definition specific to rural area has not been made. As a general statement, sparsely populated areas with a wide natural environment where the dominant economic activity is agriculture are considered rural areas (Ministry of Development, 2018).

According to the National Rural Development Strategy (2014-2020) Reported, which entered into force in 2015, two different definitions are used by TURKSTAT in statistics. The administrative status shapes the first definition. Settlements other than city district centers, including towns, are included in the definition of the villages and the city. The population threshold shapes the second definition, and provincial district centers, towns, and villages with less than 20,000 are accepted as "rural settlements". Since 1988, TURKSTAT has prepared its statistics based on these definitions by noting the distinction between rural and urban areas. However, amendments in 2012 to the Law No. 6360 made it difficult to determine the scope of rural areas and brought out the necessity of renewing the definition of rural areas. Current definitions made by TURKSTAT continue to be used until the aforementioned studies are completed (GTHB, 2015).

As it can be inferred from the explanations above, different definitions can be made of rural areas in districts with defined borders at the provincial level. Rural areas are referred to in the definitions as "rural area" or "rural settlement" but these definitions actually mean different things. In the definition of rural areas, it is necessary to take into account the natural characteristics of lands as well as the demographic, social, legal approaches.

\subsubsection{Key Legislation on Rural Area}

The laws, which were promulgated in the Official Gazette (OG) after the proclamation of the Republic, shaped the administrative structure, jurisdiction and duties of the departments providing services to the rural areas. After 1960, development plans were put into practice in an attempt to resolve basic problems in rural areas. However, developments related to planning and implementation were limited. The laws and regulations were examined in detail by years and the resulting regulations were included.

Village Law: Pursuant to this law, which was enacted in 1924 and was the first regulation for villages, which are the smallest settlements in rural areas, locations with a population of less than 2,000 individuals are called "village"; locations with a population of 2,000-20,000 are called "towns" and those with a population of more than 20,000 are called "city". All the fields, vineyards, gardens, meadows, olive groves, etc. that customarily belong to the village as well as houses, fields and pastures scattered in the mountainous and forested areas that are located within the borders of the village are considered to belong to the nearest village, and the lands, mountains, forests and plateaus that lay between two villages and thus, ambiguous are excluded from the boundaries of village (OG, 1924).

Pursuant to the 1985 Zoning Law and the Regulation for Unplanned Areas Zoning Regulation, new arrangements were made for village settlements that are outside the borders of municipality (OG, 1985a). This law and regulations continued to be applicable to spaces that abandoned their village status to be transformed into neighborhoods in accordance with the (2012) Law No. 6360, have population of less than 5,000 people and preserve their the rural settlement characteristics. (OG, 2012). 
Forest Law: Under the Law No. 3537 enacted in 1937, the title of forests the rights of villagers to benefit from forests were defined. The Law also aimed to protect forests and prevent impairing conditions (OG, 1937).

Regulations on the use of forest land by forest villagers were included in the Forest Law No. 6831, which was enacted in 1956. The General Directorate of Forestry is authorized by this law for works in state-owned forests and a forestation can be implemented according to their plans (OG, 1956).

Pursuant to the Regulation on Supporting the Development of Forest Villagers (1997), the improvement and utilization of lands such as pastures, winter pastures that could be turned into fertile agricultural lands in areas outside the forest boundaries and the development of forest villagers who would settle in these areas were supported (OG, 1997).

Law on Services to Villages: "General Directorate of Rural Services", one of the departments providing services to rural areas, was established with the Law No. 3202 and dated 1985. Efficient use, protection and development of soil and water resources, ensuring the proper use of agricultural lands, cooperating with other organizations for this purpose, making non-arable lands suitable for agriculture, establishment of onfarm systems for the convenient use of water in agricultural areas and consolidation of degraded lands where agricultural production is not made were included in the roles of the General Directorate of Rural Services (OG, 1985b).

The General Directorate of Rural Services was abolished by the Law No. 5286 dated 2005 and transferred to metropolitan municipalities in Istanbul and Kocaeli provinces, of which powers relied on the provincial borders for the first time, and to Special Provincial Administrations in other provinces (OG, 2005a).

Pasture Law: The Law No. 4342 \& dated 1998 states that the right to usufruct of pastures and summer and winter pastures may belong to one or more villages or municipalities, these areas cannot be used for other purposes, their boundaries cannot be changed, but the right to usufruct may be leased (OG, 1998).

The law aims to ensure that pastures, summer and winter pastures and meadows are inspected and protected, to change their usage patterns when necessary, to allocate such fields on behalf of village or municipal legal entities, to increase their productivity and to sustain them by carrying out maintenance or rehabilitation activities (OG, 1998).

The Law No. 6360 and dated 2012 stipulates that village guards will continue their duties in rural areas such as forests, pastures, meadows, summer and winter pastures, which were transformed from the village status to the neighborhood status and they may exercise the rights under the Village Law No. 442, Pasture Law No. 4342 other relevant laws, and takes the rights granted to villagers and forest villagers under protection (OG, 2012).

Law on Soil Conservation and Land Use: The Law No. $5403 \&$ dated 2005 emphasizes the importance of local, regional, country-scale land use plans drawn up by the Ministry or authorized institutions and organizations in order to conserve the soil and prevent misuse of agricultural lands (OG, 2005b).

Agriculture Law: The Law No. 5488 \& dated 2006 authorizes the Ministry with other relevant public bodies in connection with rural areas. It aims to secure rural development e-ISSN: 2148-2683 by stating that rural development plans, programs, projects and agricultural support activities in Turkey will contribute not only to agriculture but also to the social economic development of the rural population (OG, 2006).

With the implementation of the Strategic Environmental Assessment Regulation, which entered into force on 08.04.2017; The Ministry of Environment and Urbanization aims to protect and develop natural assets, prevent pollution, protect cultural heritage and develop sustainable plans by taking into account human health, population, migration movements and economic impacts. This regulation has been a very comprehensive legislation that determines the framework of investments prepared by public institutions in many sectors such as tourism, transportation, industry, energy, agriculture and concerns different stakeholder groups (Dikmen, 2019).

The ministerial authorizations in connection with the land use plan and rural development plan are included in some laws such as the Law on Soil Conservation and Land Use and Agriculture Law. In addition to the authority of the Ministry of Agriculture and Forestry in this regard, the Ministry of Environment and Urbanization is also authorized to make upperlevel plans, which may result in confusion of authority. It is of paramount importance that the plans in different fields are consistent with each other. Therefore, the authorized institutions organizations work in coordination.

\subsection{Developments in Public (Municipal) Housing}

Istanbul Sehremaneti Administration, the first legal establishment of the municipality, was set up upon the official notification dated 1854 (Hijri). After the proclamation of the Republic, occidental urban planning and municipality establishment works, which were launched in the Ottoman period, were accelerated and the "1876 (Hijri 1293) New Wilayat (Provincial Municipalities) Law" and the "1921 (Hijri 1340) Ankara City Hall Law" were repealed and the Municipality Law No. 1580 was enacted in 1930. Until 1954, the municipality and the special administration were integrated in Istanbul and continued in the form of a unified administration structure. The 1961 Constitution on local administrations divided the administration in the country into "central administration" and "local administration", and created a framework that would enable municipalities to develop more autonomously stronger (Suri \& Kansu, 1999).

Apart from the central municipality, Kartal, Tuzla and Silivri municipalities also served in Istanbul before the proclamation of the Republic and 5 new municipalities, i.e., Catalca, Maltepe, Pendik, Sile and Yalova, were set up in 1923 1930. Kucukcekmece, Buyukcekmece Municipalities were set up in 1950-1960 and 24 new municipalities were established in 1960-1978 around Istanbul Central Municipality (Suri \& Kansu, 1999).

The Statutory Decree No. 195 promulgated in the Official Gazette (OG) in 1984 aimed to establish a two-tier management style by establishing metropolitan and district municipalities. Accordingly, central districts were recognized as separate districts and a "metropolitan municipality" bearing the name of the "Buyuksehir" and "district municipalities" named after the districts within the borders of the metropolitan municipality were formed. In accordance with the Law No. 3030, which was enacted in the same year, metropolitans adopted a different 
management style as "metropolitan cities" (OG, 1984; as cited in Suri \& Kansu, 1999).

Towns established according to the Law No. 7469 enacted on $04 / 05 / 1960$ and "town municipalities" that were located within the metropolitan municipality borders specified in the Law No. 3030 and excluded from the powers of Metropolitan Municipality, shown in Figure 3, existed. Tuzla, Pendik, Kartal and Umraniye district municipalities were under the responsibility of Istanbul Metropolitan Municipality, but Sultanbeyli district, Alemdag, Samandira, Sarigazi, Sultanciftligi and Yenidogan town municipalities were out of this responsibility during this period. In other words, although some towns were within the jurisdiction of the metropolitan municipality, they were left as independent municipalities outside the authority of the metropolitan municipality. When evaluated from the perspective of the integrity of space, planning and services, this resulted in a complex structure (Suri, 2004).

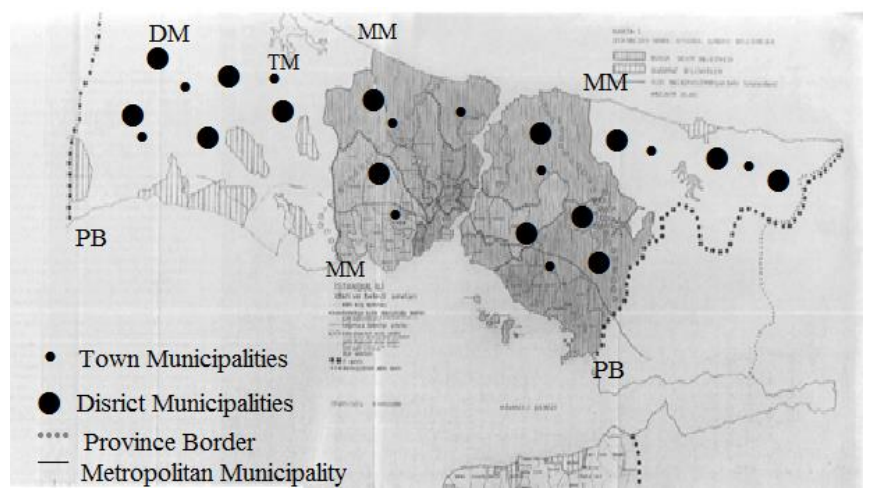

Figure 3. Municipality Borders in the Period when Metropolitan Municipalities were Established (Suri, 1984)

Upon the enactment in 2004 of the Law No. 5216, which reconstructed the powers of the Metropolitan Municipality, Law No. 3030 was abolished.

\subsubsection{Authority and Boundary Changes in Metropolitan Municipalities pursuant to the Metropolitan Municipality Law No. 5216}

Pursuant to the Law No. 5216, which was enacted in 2004, the town municipalities within the boundaries of the metropolitan municipalities were rescinded. The structure of metropolitan city was classified as "metropolitan, district and first-tier municipalities". Metropolitan, district and first-tier municipalities were authorized to protect agricultural lands additionally water basins and to carry out reforestation (OG, 2004).

The boundaries of Istanbul and Kocaeli metropolitan municipalities were extended to the provincial administrative boundaries, and the legal personalities of the villages and towns within the boundaries of metropolitan municipality terminated and they were transformed into neighborhoods pursuant to this law. The legal personality of the forest villages in rural areas was stated to be maintained in accordance with the same law.
The Municipal Law No. 5393, adopted in 2005, handled the municipality, town and neighborhood administrative units holistically (OG, 2005c). Pursuant to this law, both the Metropolitan Municipality Law No. 5216 and the Municipal Law No. 5393 started to be executed in metropolitan municipalities.

\subsubsection{Rescinding Some First-Tier Municipalities with Law No. 5747}

Legal personalities of some of the first-tier municipalities within the metropolitan cities specified in the law were rescinded and they were added to the district municipalities where they were located as a neighborhood or a part of neighborhood in accordance with the Law No. 5747 on the Establishment of District Municipalities within the Boundaries of Metropolitan Municipalities and Amendments to Certain Laws that entered into force in 2008 (OG, 2008).

In 2012, first-tier municipalities were rescinded in all metropolitan cities, and the municipal structure was reorganized as metropolitan and district municipalities in accordance with the Law No. 6360 (OG, 2012).

\subsubsection{Extending the Metropolitan Municipalities to the Provincial Administrative Boundaries and Status Changes with Law No. 6360}

Pursuant to the Law No. 6360, enacted in 2012, new metropolitan municipalities were established and the borders of all metropolitan municipalities were extended to the provincial administrative boundaries. The legal personalities of villages and town municipalities in all metropolitan cities were rescinded with this law, and villages were added as neighborhoods and municipalities were added as a single neighborhood with the name of the town into the district municipalities they were affiliated (Figure 4).

Within the scope of Law No. 6360, the first-tier municipalities were abolished and only the definitions of metropolitan and district municipalities were included. In addition, in provinces that became metropolitan municipalities, the legal personalities of the provincial special administrations were terminated, and they were attached to the relevant units of local or central bodies.

With the changes in the structure of metropolitan cities, the metropolitan and district municipalities were authorized to carry out all types of activities and services to support agriculture with the Law No. 6360, in order to provide services to the areas preserving their rural characters. However, no regulation was made to determine rural areas (OG, 2012).

Considering the issues specified in the Law No. 7254 enacted on $16 / 10 / 2020$, it is stated that the neighborhoods that have been transformed into neighborhoods within the boundaries of metropolitan municipalities and detected to have the characteristics of rural settlement can be accepted as "rural neighborhoods", but the qualification of rural neighborhood or rural settlement area can be removed with the procedure set forth in the law (OG, 2020). 


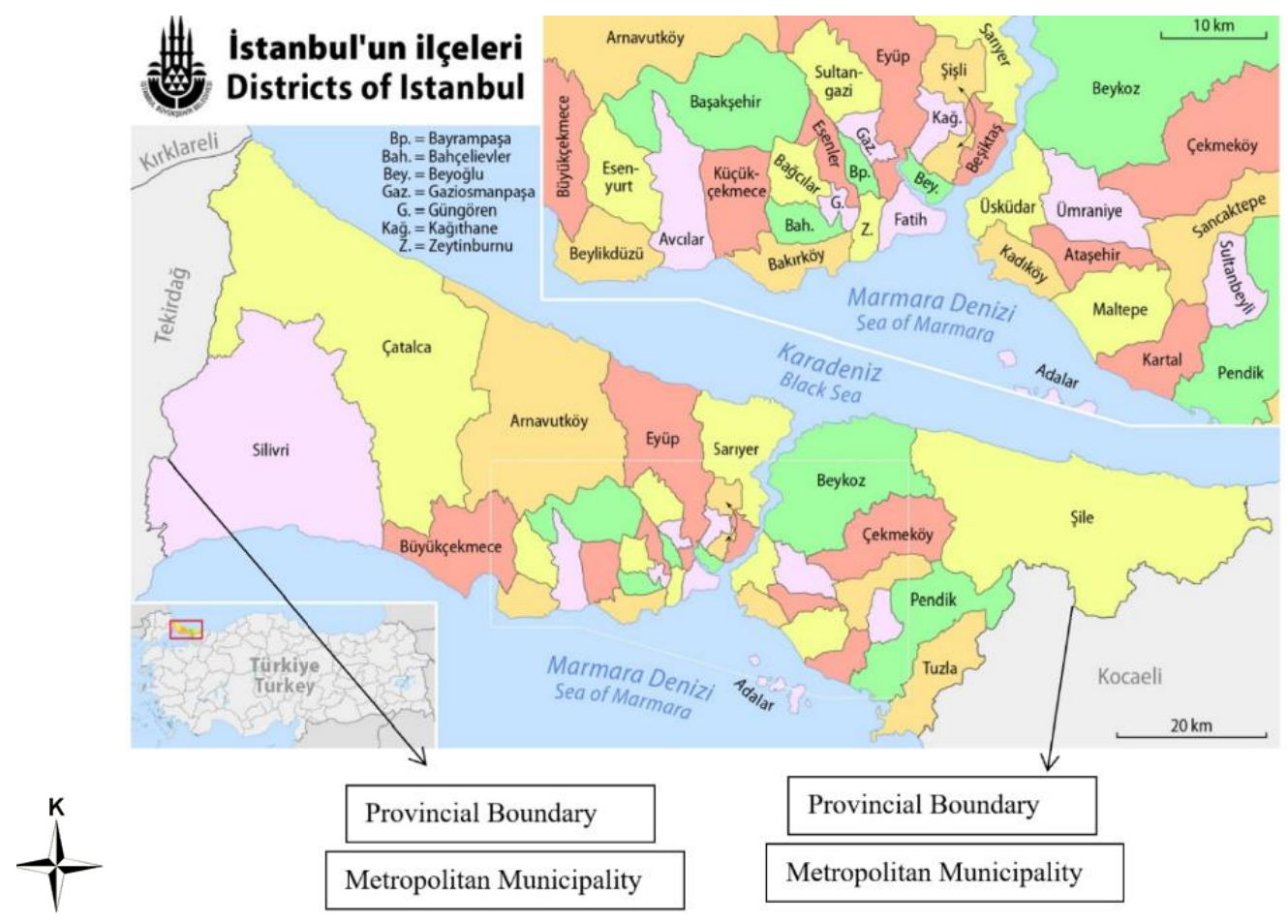

Figure 4. Transforming Villages and Towns into Neighborhood Status by Extending the Metropolitan Municipalities to the Provincial Administrative Boundaries (Url-2, 2021)

\section{Results and Discussion}

\subsection{Agricultural Potentials of the Rural Neighborhoods within the Provincial Boundaries of Istanbul}

The rural neighborhoods are under housing pressure in metropolitan cities with rapidly increasing population. On the other hand, all food needs in the metropolitan cities are met from long distances. Plans should be handled with a holistic approach (Aksu, 2014). In 2019, household consumption expenditures in Turkey were realized in Istanbul metropolis, which has the highest population, with a share of $24.4 \%$ (TURKSTAT, 2020b).

The research will be carried out within the scope of the Istanbul metropolis, as it proposes values that will make the maximum contribution to the city's environment and the country in general and sets an example for other metropolitan cities in a global competitive environment. Revealing the current agricultural potential of the city will create a significant amount of added value in and around the city.

Maintaining the sustainability of the natural resources by using the existing lands in rural neighborhoods in the optimum manner in line with the natural resources, and the ability of the potentials in these areas to meet a specific part of the food needs of the people living in the metropolitan cities will be beneficial in many aspects.
The province of Istanbul, chosen as the study area, is a large city located between $41^{\circ} 61^{\prime}-40^{\circ} 79^{\prime}$ north latitudes and $27^{\circ} 94^{\prime}-$ $29^{\circ} 97$ east longitudes having the Black Sea in the north, the Sea of Marmara in the south and the Bosporus (Istanbul Strait) in the middle, connecting Asia and Europe. Neighboring Kocaeli in the east, Tekirdag and Kirklareli in the west, Istanbul is surrounded by the Black Sea in the north, the Sea of Marmara and the Golden Horn in the south. The Princes' Islands in the Sea of Marmara are also included in Istanbul province. Istanbul is the center and a global city of both the Marmara Region and Turkey (Url-3).

With the Metropolitan Municipality Law No. 5216, the boundaries of the Istanbul Metropolitan Municipality (IMM) have extended to the provincial administrative boundaries and increased to $5343,02 \mathrm{~km}^{2}$ from 1830,92 $\mathrm{km}^{2}$ (IMM, 2009).

There are 39 districts and 962 neighborhoods within the span of authority of the IMM. With the Law No. 6360, 151 villages were added as neighborhoods to the district municipalities as of 30/03/2014 (Url-4). These neighborhoods were defined as "rural neighborhoods" with the Law No. 7254 enacted in 2020. The rural neighborhoods are mostly concentrated in areas with natural resources in the north of Istanbul, as shown in Figure 5. However, there are also areas with rural characteristics, except for the stated neighborhoods. 


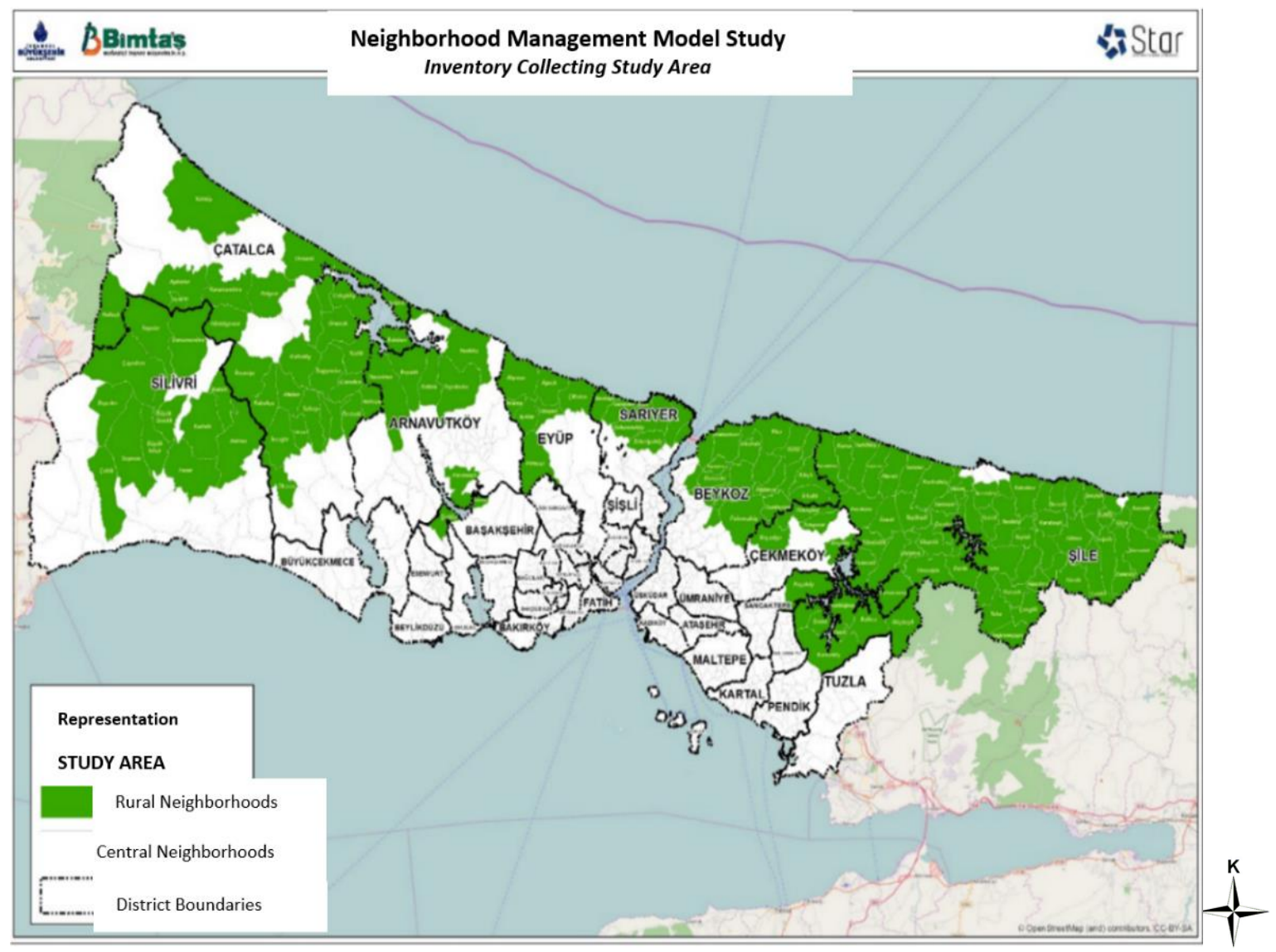

Figure 5. Rural Neighborhoods within the Provincial Boundaries of Istanbul (IMM, 2017)

151 rural neighborhoods within the provincial borders of Istanbul; There are 57 of them in Şile, 27 of them in Çatalca, 20 of them in Beykoz, 13 of them in Silivri, 8 of them in Arnavutköy and Sarıyer, 7 in Eyüpsultan, 5 in Pendik, 4 in Çekmeköy and one in Başakşehir and Sancaktepe (IMM, 2017).

When the population distribution of the districts where rural neighborhoods are located between 2011 and 2020 is examined, the total population of rural neighborhoods has increased over the years.

It is seen that the highest population increase is in the rural neighborhoods of Sariyer district. In the rural neighborhood of
Başakşehir district, the population suddenly decreased by 3,500 compared to the next year after 2012, and continued to decrease at the same levels in the following years (TURKSTAT, 2020a) (Table 1).

In the IMM rural neighborhood survey, it was observed that the distribution of people by age groups was $20 \%$ for the population over $60,16.2 \%$ for the 50-59 age group, and $15.6 \%$ for the 20-29 age group. Since a large part of the population is in the active population (15-65), it is possible to say that it is young and economically active (IMM, 2017).

Table 1. Population Trends of Rural Neighborhoods by Districts (TURKSTAT, 2020a)

\begin{tabular}{lrrrrrr}
\hline Districts with Rural Population & $\mathbf{2 0 1 1}$ & $\mathbf{2 0 1 2}$ & $\mathbf{2 0 1 3}$ & $\mathbf{2 0 1 4}$ & $\mathbf{2 0 1 5}$ & $\mathbf{2 0 2 0}$ \\
\hline Arnavutkoy & 7.983 & 8.134 & 8.188 & 8.192 & 8.879 & 9.303 \\
\hline Basaksehir & 4.103 & 5.081 & 1.496 & 1.455 & 1.440 & 1.236 \\
\hline Beykoz & 25.209 & 25.988 & 27.704 & 26.557 & 27.347 & 28.600 \\
\hline Catalca & 26.787 & 26.604 & 26.595 & 26.506 & 26.378 & 26.813 \\
\hline Cekmeköy & 4.886 & 4.892 & 5.048 & 5.012 & 5.113 & 5.488 \\
\hline Eyupsultan & 6.802 & 7.042 & 6.546 & 6.905 & 6.765 & 6.400 \\
\hline Pendik & 3.628 & 3.597 & 3.540 & 3.562 & 3.455 & 3.819 \\
\hline Sancaktepe & 1.660 & 1.686 & 1.644 & 1.703 & 1.746 & 1.708 \\
\hline Sarıyer & 31.617 & 31.924 & 34.169 & 36.122 & 39.252 & 40.967 \\
\hline Silivri & 12.517 & 12.322 & 12.357 & 12.083 & 11.968 & 11.808 \\
\hline Sile & 15.996 & 16.958 & 17.683 & 18.485 & 18.884 & 20.545 \\
\hline Total & $\mathbf{1 4 3 . 1 9 9}$ & $\mathbf{1 4 6 . 2 4 0}$ & $\mathbf{1 4 6 . 9 8 3}$ & $\mathbf{1 4 8 . 5 9 6}$ & $\mathbf{1 5 3 . 2 4 2}$ & $\mathbf{1 5 6 . 6 8 7}$ \\
\hline & & & & & &
\end{tabular}




\subsubsection{Agricultural Land Use of Istanbul}

With the Law No. 5403 on Soil Preservation and Land Use, "agricultural lands" where fertile soils exist are classified as absolute, marginal, special product, cultivated agricultural lands according to their usage (OG, 2005b). In Figure 6 and Figure 7, various land use and land cover studies carried out by IMM in different years are given below.

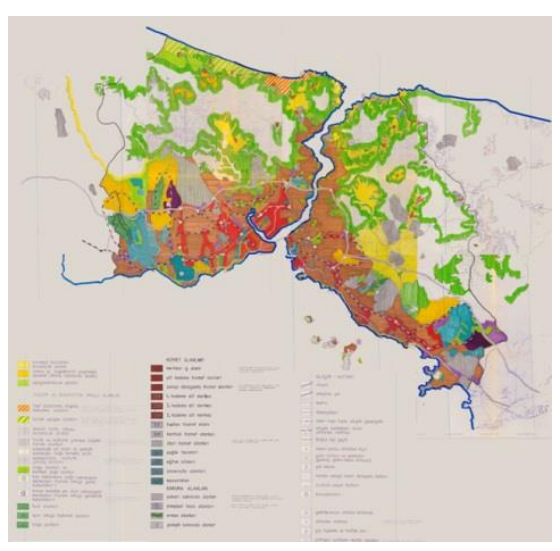

Figure 6. 1/50.000 scale Istanbul Metropolitan Area Subregion Master Plan (IMM, 1994)

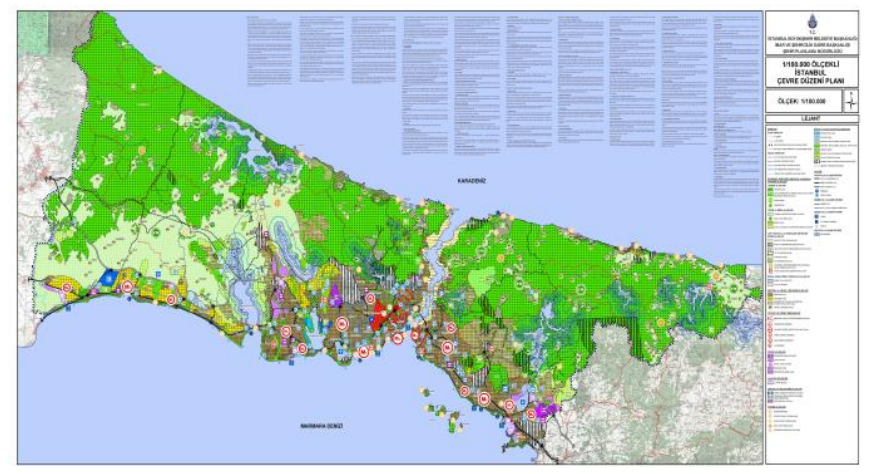

Figure 7. 1/100,000 scale Istanbul Provincial Environmental Plan (IMM, 2009)

The land use in the province of Istanbul in 2017 is shown in Figure 8. Table 2 includes the amount of agricultural lands in 2019. Accordingly, there is a total of 98,607 ha of agricultural land in Istanbul (TOB, 2019).

Tablo 2. Size of Agricultural Lands of Istanbul (TOB, 2019)

\begin{tabular}{ll}
\hline Distribution of Agricultural Lands & Amount (ha) \\
\hline Dry Absolute Agricultural Land & 72,670 \\
\hline Irrigated Absolute Agricultural Land & 6,600 \\
\hline Dry Marginal Agricultural Land & 15,424 \\
\hline Irrigated Marginal Agricultural Land & 120 \\
\hline Dry Special Product Land & 251 \\
\hline Irrigated Special Product Land & 811 \\
\hline Greenhouse & 136 \\
\hline Total & $\mathbf{9 8 , 6 0 7}$ \\
\hline
\end{tabular}

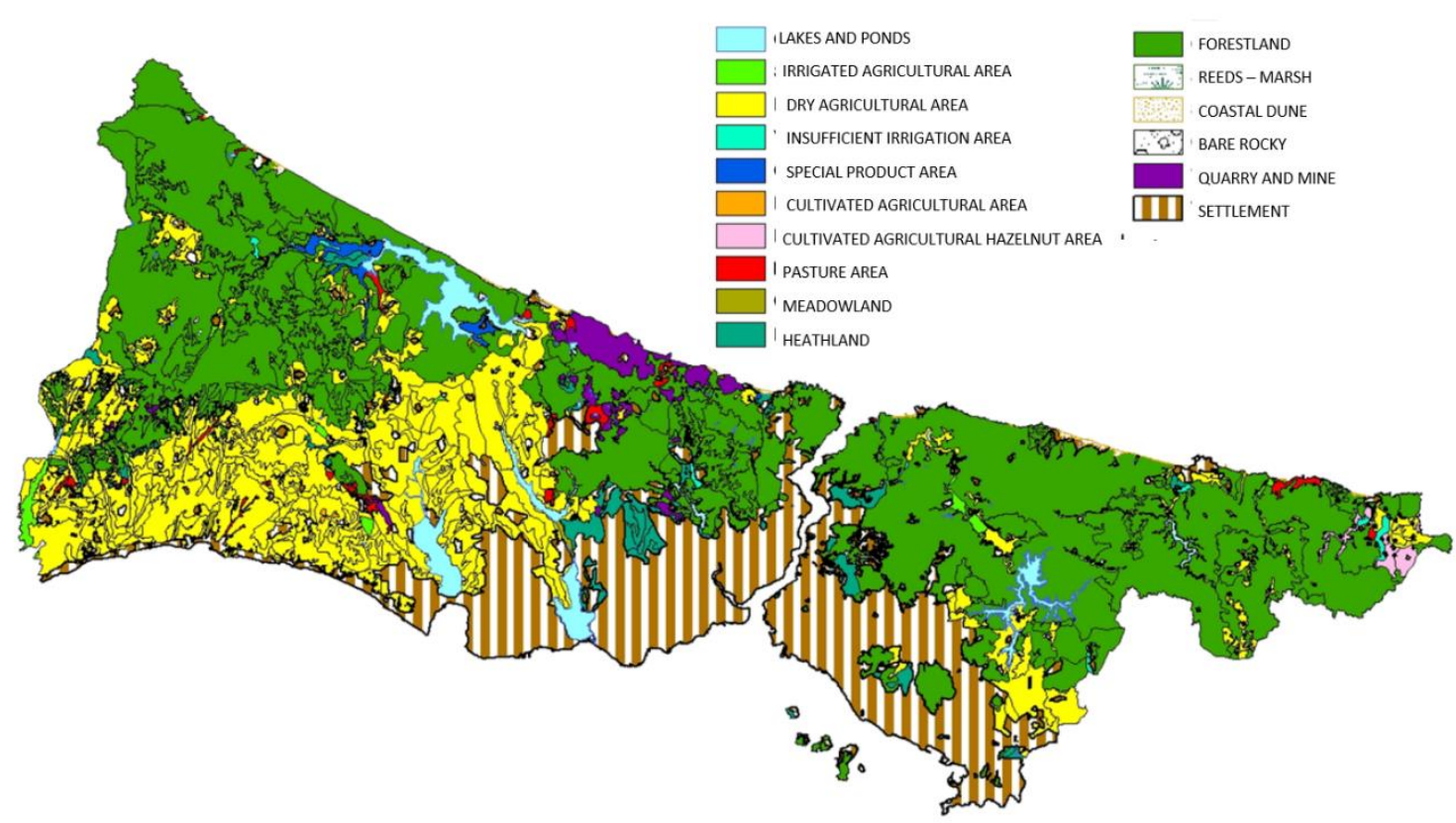

Figure 8. Map of Land Use of Istanbul Province (IMM, 2017) 
Agricultural areas in the whole of Istanbul are concentrated in the rural areas of Çatalca and Silivri districts in the western part of the European side, Beykoz on the north coast of the Anatolian side, Şile in the northeast, and Çekmeköy districts in the interior. Forestlands are widely located in the northern parts of both the Anatolian and European sides.

As shown in Figure 9, 18.1\% agricultural land, 1.1\% pasture-meadowland, $43.6 \%$ forest and heathland, $35.1 \%$ nonagricultural area and $2.1 \%$ lake and dam area are available according to forms of land use within the provincial boundaries of Istanbul (TOB, 2019).

This classification, which can be defined as a general land classification system rather than a soil classification feature, is mostly used for the purpose of land use planning at macro level. Land use classes are required for a more detailed classification. For this purpose, Istanbul province 2009 AKK maps were used.

\section{Forms of Land Use}

\section{1}

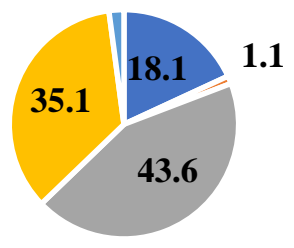

- Agricultural Land

- Pasture-Meadowland

- Forest and Heathland

- Built-in Space and Equipment

- Lake and Dam Area

Figure 9. Forms of Land Use of Istanbul Province (TOB, 2019)

\subsubsection{Land Use Capability (LUC) Classes of Istanbul Province}

It is required to make land use plans in accordance with the characteristics of the land in order to know the soil better and to benefit from it more efficiently and sustainably by preventing its degradation. Soil surveys are performed and the soil classes of the land are determined in line with these plans (IMM, 2009).

According to the Soil and Land Classification Standards Technical Instruction Report prepared by the Ministry of Agriculture and Forestry in accordance with the Law No. 5403, lands are classified among the $1^{\text {st }}$ class, where the most fertile agriculture can be done, and $8^{\text {th }}$ class lands, which are not suitable for agriculture and can only be utilized as recreation areas or national parks (TOB, 2012). In Table 3, the suitability of LUC classes for agriculture is shown, and in Figure 10, the map of LUC within the boundaries of IMM is given.

Table 3. Suitability for Agriculture of LUC Classes (IMM, 2017)

\begin{tabular}{ll}
\hline Classes of Land & Suitability for Agriculture \\
\hline $\mathbf{1}^{\text {st }}$ Class & The most fertile agricultural land \\
\hline $\mathbf{2}^{\text {nd }}$ Class & Pretty good agricultural land \\
\hline $\mathbf{3}^{\text {rd }}$ Class & Agricultural land with medium fertility \\
\hline $\mathbf{4}^{\text {th }}$ Class & Lands with restricted use in agriculture (meadow, pasture, etc.) \\
\hline $\mathbf{5}^{\text {th }}$ Class & Lands that will be suitable for agriculture after improvement \\
\hline $\mathbf{6}^{\text {th }}$ Class & Special product land \\
\hline $\mathbf{7}^{\text {th }}$ Class & Non-agricultural lands \\
\hline $\mathbf{8}^{\text {th }}$ Class & Non-agricultural lands \\
\hline
\end{tabular}




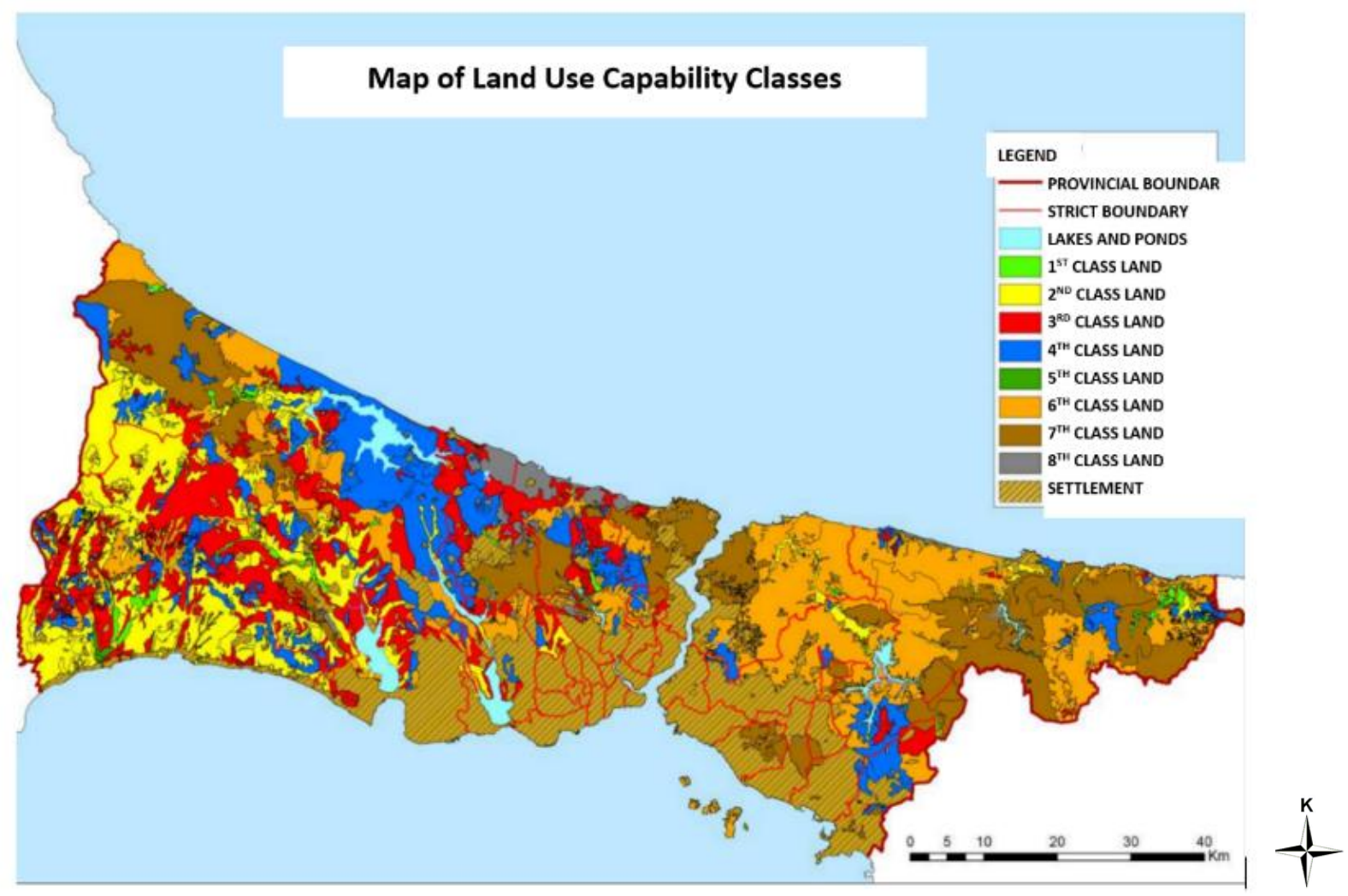

Figure 10. Land Use Capability Classes of Istanbul Province (IMM, 2009)

When the distribution of LUC in the province of Istanbul is examined, $1^{\text {st }}$ class lands are very rare and located in the northeastern and western parts. $2^{\text {nd }}$ class lands are centered in the western and northwestern parts of the European side. $3^{\text {rd }}$ class lands are generally distributed in large parts in the south of the Anatolian side and throughout the European side and primarily in the northern part together with the $4^{\text {th }}$ class lands. There are scarcely any $5^{\text {th }}$ class lands, and $6^{\text {th }}$ class lands are mostly common in the middle and northern parts of the European side and in the north of the settlement areas of the Anatolian side. $7^{\text {th }}$ class lands are mainly in the northwest and northeast of the European side and in the eastern part of the Anatolian side. $8^{\text {th }}$ class lands are distributed in the northwestern part towards the Black Sea coasts (Figure 10).

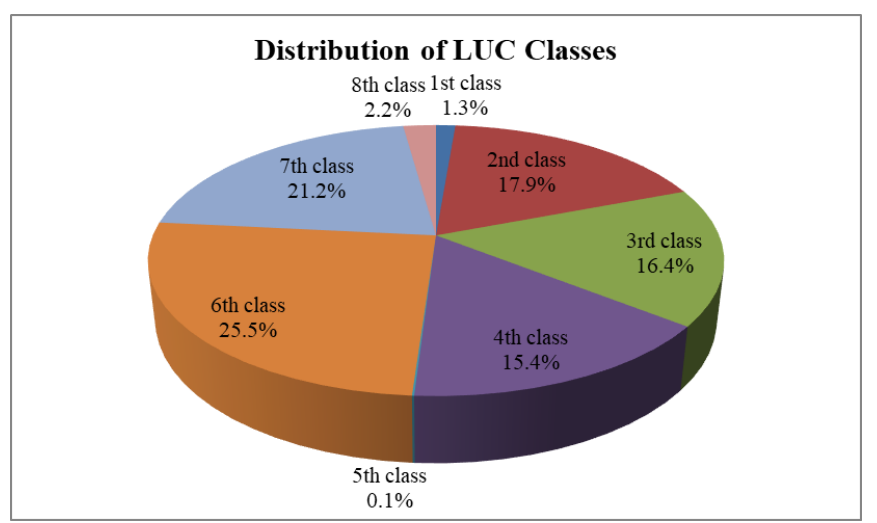

Figure 11. Proportional Distribution of LUC Classes in Istanbul Province (IMM, 2017)
Although Istanbul seems quite limited in $1^{\text {st }}$ class lands due to its rough topography, slope, erosion and other factors restricting soil use, $2^{\text {nd }}, 3^{\text {rd }}, 4^{\text {th }}$ class lands, where agriculture can be done after soil improvement, are of great importance. $1^{\text {st }}, 2^{\text {nd }}$, $3^{\text {rd }}$ class lands account for only $35.6 \%$ (146,599 ha) of all lands, and $6^{\text {th }}, 7^{\text {th }}, 8^{\text {th }}$ class lands constitute almost $50 \%(205,791 \mathrm{ha})$ (Figure 11). In addition, the $6^{\text {th }}$ class lands, making up the largest part of the total of 420,575 ha land of Istanbul province, have $25.5 \%(107,141 \mathrm{ha})$ area. $7^{\text {th }}$ class lands cover $21.2 \%(89,241$ ha) area (Table 4).

It appears that 113,727 ha of the 534,302-ha area owned by Istanbul province with the extension of the municipal boundaries comprises of settlement areas, excluding the 420,575-ha area calculated based on the land use classes.

According to Table 3, there are 4,946.6 ha of irrigated agriculture and insufficient irrigation areas throughout the province. Approximately $68 \%$ of the irrigated agricultural areas are on the European Side, in Catalca and Silivri. On the Anatolian side, the most irrigated agricultural area is in Sile. 123,624.4 ha of dry farming area in the whole of Istanbul; 109,192 hectares are on the European Side (48\% in Silivri, 39\% in Catalca, $6 \%$ in Büyükcekmece), 14,432,4 hectares in the Anatolian Side (28\% in Tuzla), 31\% in Sile, 23\% in Pendik). The main products obtained from agricultural areas are wheat (57\%) and sunflower (24\%). Approximately $57 \%$ of wheat cultivation areas are in Silivri and 34\% in Catalca (IMM, 2017). 
Table 4. Distribution of Forms of Land Use According to Capability Classes in Istanbul Province (IMM, 2017)

\begin{tabular}{|c|c|c|c|c|c|c|c|c|c|}
\hline \multirow[t]{2}{*}{ Forms of Land Use } & \multicolumn{9}{|c|}{ Land Use Capability Classes (ha) } \\
\hline & $\begin{array}{c}\text { 1st } \\
\text { Class }\end{array}$ & $\begin{array}{c}\text { 2nd } \\
\text { Class }\end{array}$ & 3rd Class & 4th Class & $\begin{array}{c}\text { 5th } \\
\text { Class }\end{array}$ & $\begin{array}{c}\text { 6th } \\
\text { Class }\end{array}$ & 7th Class & $\begin{array}{c}\text { 8th } \\
\text { Class }\end{array}$ & Total (ha) \\
\hline Irrigated Farming & 482.3 & 2727.5 & 28.7 & & & & & & 3238.5 \\
\hline Dry Farming & 2982.5 & 45609.1 & 36622.8 & 24916 & 475.5 & 12082.7 & 935.8 & & 123624 \\
\hline $\begin{array}{l}\text { Insufficient Irrigated } \\
\text { Farming }\end{array}$ & 735.3 & 844.4 & 101.9 & & & & 26.5 & & 1708.1 \\
\hline Cultivated Farming & 659.4 & 235.1 & 88.8 & 79.2 & & 1097.6 & 45.5 & & 2205.6 \\
\hline Special Product & 78.6 & 1774 & 45.5 & 611.3 & & & & & 2509.4 \\
\hline Meadow & & 261.3 & 274.4 & & 83.9 & & & & 619.6 \\
\hline Pasture & 38.2 & 635.1 & 1389.9 & 394.3 & & 634.9 & 638.4 & & 3730.8 \\
\hline Heathland & 24.7 & 1187.8 & 2510.7 & 2534.4 & 18.9 & 3129.4 & 2004.2 & & 11410.1 \\
\hline Forest & 446.6 & 21948.5 & 27868.1 & 36068.6 & & 90196.9 & 85590.9 & & 262120 \\
\hline Reeds - Marsh & & & & & & & & 135.5 & 135.5 \\
\hline Coastal Dune & & & & & & & & 907.8 & 907.8 \\
\hline Bare Rocky & & & & & & & & 87.1 & 87.1 \\
\hline Quarry and Mine & & & & & & & & 8278.3 & 8278.3 \\
\hline Total & 5447.6 & 75222.8 & 68930.8 & 64603.8 & 578.3 & 107142 & 89241.3 & 9408.7 & 420575 \\
\hline
\end{tabular}

\subsection{Product Values for Meeting Food Needs in Istanbul Province}

In this study, an approximate calculation will be attempted to be made based on only the amount of vegetable and fruit production among the agricultural products feeding the metropolitan city. Calculations on the total amount of products can be evaluated in different studies. The land use data of TOB and IMM for 2018 and the production value obtained for the same year are proportioned over the population.

\subsubsection{Amount of Agricultural Products}

In Istanbul, having a population of $15,067,724$ people as of 2018 , the amount of agricultural product per person consumed in 2018, based on the population and production amount, is 187 $\mathrm{kg} /$ year (Url-5).

In the city, having 78,531 tons of annual vegetable and fruit production within the provincial boundaries in 2018 according to TOB data, most of the vegetable and fruit needs are met from outside the city. In 2018, the total vegetable fruit amount coming to the Wholesale Market from inside and outside the city was 2,816,408 tons per year (IMM Directorate of Wholesale Markets, 2018). This indicates that approximately $3 \%$ of the amount of vegetable fruit products consumed in Istanbul is obtained by growing within its boundaries. Currently, $3 \%$ of the production is done within the provincial borders of Istanbul. However, the production rate will reach about $8 \%$ when the agricultural fields are planted in line with their capacity.

Considering the existing cultivated area of Istanbul in 2018, if the suitability for agriculture of the rural areas according to land use capability classes is also taken into account, the cultivation area potential can be increased approximately to $35.5 \%$ and agricultural production can be performed in these areas as well.

\section{Conclusions and Recommendations}

This study has been prepared to investigate the sustainability and evaluation of the agricultural potentials of the village and its surrounding rural areas, which gained the status of rural neighborhood after the Istanbul metropolitan municipality

borders were based on the provincial borders. The fact that these areas, which were taken within the boundaries of the municipality, can be opened to construction in the zoning plans, immediately increased the importance of their protection within the scope of rural planning.

It is observed that agricultural production continues in rural areas according to the characteristics of the land, regardless of villages or neighborhoods with changed status within the provincial boundaries of Istanbul. Although it is not possible to provide all the food needed in Istanbul within the city, the capacity can be increased by implementing plans and projects to satisfy a part of the need, support rural development at the local level. In order to preserve areas whose statuses have been changed by extending the boundaries of the metropolitan municipality to the provincial administrative boundaries, but which still have natural resources and agricultural potential, it is required primarily:

- To define the "rural area" "rural settlement" concepts accurately,

- To determine all actors from planning to implementation,

- To identify the inventory determining the potentials,

- To carry out planning studies from upper scale to lower scale according to the land size,

- To train and raise awareness of the producers,

- To determine the strategic production plan,

- To provide product evaluation and market opportunities,

- To give incentives and supports so as to provide added value,

- To meet the sociocultural needs of the rural population,

- To ensure integration of urban-rural settlements,

- To make urban plans protecting rural areas from urbanization pressure.

- Efforts including not neglecting the control of housing, environmental control and agricultural product control 
will be able to make multilateral contributions to the sustainability of the rural areas and rural settlements within the metropolitan boundaries by maintaining their characters.

Every day, Istanbul's daily food needs are brought from kilometers away. According to TOB data in 2018, only vegetable and fruit production grown within the borders of Istanbul was 78,531 tons. In addition, according to IMM data, the total number of vegetables and fruits coming to Istanbul from abroad in 2018 is 2,816,408 tons. When the data produced and become available in Istanbul are considered together, it is seen that approximately $3 \%$ of the total vegetables and fruits for consumption are met within its own borders.

In 2018, approximately 75,760 hectares of land in Istanbul was reserved for current plant production, and 78,531 tons of yield was obtained from only vegetable and fruit production. In fact, it has a production capacity of 214.205 hectares in all of the lands that can be cultivated (I-IV class) according to the Istanbul AKK distribution. If production is made in line with this capacity, 222,039 tons of fruit and vegetables will be produced. If this production amount is provided, $8 \%$ of the total vegetables and fruits can be met within the provincial borders. In addition to 75,760 hectares of total cultivation area, if production is made on an area of 214.205 hectares, the plant production capacity will be $35.5 \%$. Whether such a production is economically sufficient for rural settlements is a separate issue.

It is ensured that the products grown in and around the city are transported in more durable conditions with minimum transfer cost. In this way, the negative effects of vehicles coming from long distances can be reduced and efficiency can be achieved both naturally and economically. At the same time, as accident risks will decrease, positive results can be obtained in terms of occupational safety and health (OHS). Besides, the over-crowdedness in the city occurring due to migration movements from the rural areas will be prevented, and the economic self-sufficiency provided by the rural life to the city will contribute to national development. If each city's own potentials are evaluated, it will be possible to prevent overpopulation in cities, as employment opportunities can be provided to people living in rural areas. As a result of these, the economic efficiency provided by rural life to the city will contribute to national development.

\section{References}

Aksu, G. A. (2014). Holistic Landscape Planning Approach, p. 21-34 Istanbul Commerce University, Journal of Science, 13 (26).

Cetiner, A. (1980). Rural Settlements and Physical Arrangement Principles. Istanbul Technical University Faculty of Architecture, 87, Gumussuyu.

Cloke, P.J., \& Park, C.C. (1985). Rural Resource Management. Croom Helm, 473p, Sydney, Australia.

Dikmen, A.C. (2019). Strategic Environmental Assessment (SEA) Regulations Contribution to Turkey's Environment Policy. European Journal of Science and Technology, (15), 535-541.

DPT (2000). Eighth Five-Year Development Plan, Rural Development Specialization Commission Report, Ankara, 2000 .
FAO (2019). Food Security and Nutrition Status in the World (Full Text). Taking Precautions Against Economic Slowdown and Recession, 30.

FAO (2021). World Food and Agriculture-Statistical Yearbook 2021. Rome. https://doi.org/10.4060/cb4477en.

GTHB, (2015). National Rural Development Strategy, 20142020. Date of Access: 10.01.2021. https://kkp.tarim.gov.tr/UKKS\%20(2014-2020).pdf

Halfacree, K.H. (1993). Locality and Social Representation: Space, Discourse, and Alternative Definitions of the Rural. Journal of Rural Studies, 9(1): 23-37. ISSN: 1305-7820, EISSN: 2587-165X.

Ilbery, B. (Ed.) (1998). The Geography of Rural Change. Addison Wesley Longman Limited. 267p, London.

IMM (1994). 1/50.000 scale Istanbul Metropolitan Area Subregion Master Plan. Date of Access: 04.10.2021. https://sehirplanlama.ibb.istanbul/arsiv/

IMM (2009). Department of Reconstruction and Urban Planning, Directorate of City and Planning, 1 / 100.000 Scale Istanbul Environmental Plan Report, Third Part, Istanbul City Whole Research Findings.

IMM (2017). Directorate of Food, Agriculture and Livestock Headquarters, Neighborhood Research, Inventory Studies, Neighborhood Criteria and Neighborhood Management Model, Neighborhood Management Model Report, January 2017.

IMM Directorate of Wholesale Markets (2018). State Department Tonnage Monitoring Form.

Jamshed, A., Birkmann, J., Feldmeyer, D., \& Rana, I.A. (2020). A Conceptual Framework to Understand the Dynamics of Rural-Urban Linkages for Rural Flood Vulnerability. Sustainability, 12, 2894. https://doi.org/10.3390/su12072894

Ministry of Development (2018). Eleventh Development Plan, Rural Development Specialization Commission Report. Ankara.

OG (1924). Village Law No. 442. Issue: 68.

OG (1937). Forest Law No. 3116. Issue: 3537.

OG (1956). Forest Law No. 6831. Issue: 9402.

OG (1984). 27.6.1984. Law No. 3030 on the Amendment of the Decree-Law on the Management of Metropolitan Municipalities. Number: 18453.

OG (1985a). 3.5.1985. Zoning Law No. 3194. Issue: 18749.

OG (1985b). 22.5.1985. Law No. 3202 on Services for the Village. Issue: 18761 .

OG (1997). Regulation on Supporting the Development of Forest Villagers. Issue: 23066.

OG (1998). Pasture Law No. 4342. Issue: 23272.

OG (2004). 10.7.2004. Metropolitan Municipality Law No. 5216. Issue: 25531.

OG (2005a). 3.1.2005. Law No. 5286 on Abolition of the General Directorate of Rural Services and Making Amendments to Some Laws. Issue: 25710.

OG (2005b). 3.7.2005. Soil Conservation and Land Use Law No. 5403. Issue: 25880.

OG (2005c). 3.7.2005. Municipality Law No. 5393. Issue: 25874.

OG (2006), 18.4.2006. Agriculture Law No. 5488. Issue: 26149. Issue: 26148 .

OG (2008). 6.3.2008. Law No. 5747 on Establishment of Districts within the Borders of the Metropolitan Municipality and Making Amendments to Some Laws. Issue: 26824. 
OG (2012). 12.11.2012. Law No. 6360 on the Establishment of Metropolitan Municipalities and Twenty-Seven Districts in Fourteen Provinces and Amending Certain Laws and Decree Laws. Issue: 28489.

OG (2020). 16.10.2020. Law No. 7254 on the Amendment of Public Financial Management and Control Law and Some Laws. Issue: 31276.

Suri, L. (1984). Transformation of Rural Soils to Urban Soils Istanbul and Kartal Example, Yildiz Technical University, Institute of Social Sciences, Master Thesis, 138, Istanbul.

Suri, L., \& Kansu, H. (1999). Historical Development of Local Governments, Legal and Administrative Regulations, Istanbul Case. City Management, Human and Environmental Problems Symposium 99, 2, 81-95. (Full Paper / Oral Presentation).

Suri, L. (2004). Planning Demands and Applications in Drinking Water Basins. Istanbul and Water Symposium (Full Text Presentation / Oral Presentation).

TOB (2012). Technical Instruction for Soil and Land Classification Standards.

TOB (2019). Istanbul Governorship Provincial Directorate of Agriculture and Forestry, 2019 Briefing Report, Istanbul.

Tuna, A. (2021). Examination of Green Infrastructure Concept in UK through Practice Examples. European Journal of Science and Technology, (21), 416-423.

TURKSTAT, 2020a. The Results of Address Population Registration System, 2020.

TURKSTAT, 2020b. The Results of Household Consumption Expenditure (Regional), 2019.

TURKSTAT, 2021. Labor Statistics, 2020.

United Nations (2019). World Urbanization Prospects. The 2018 Revision. Methodology, Department of Economic and Social Affairs, Population Division. United Nations publication. Sales No. E19.XIII.7.

Url-1 https://population.un.org/wpp/DataQuery/ Date of Access: 08.11.2021.

Url-2 https://istanbulharitasi360.com/istanbul-ilce-haritasi Date of Access: 26.09.2021.

Url-3 http://www.istanbul.gov.tr/asya-ve-avrupayi-birlestirensehir-istanbul Date of Access: 12.05.2021.

Url-4 https://www.ibb.istanbul/SitePage/Index/82 Date of Access: 12.05.2021.

Url-5 https://www.nufusu.com/il/2017/istanbul-nufusu Date of Access: 11.02.2021.

Urgenc, S.I. (2000). Rural Landscape. Y1ld1z Technical University Press and Publishing Center, 234, Istanbul.

Yilmaz, M. (2015). Changes of Rural Population in Turkey and its Distribution By Provinces (1980-2012). Eastern Geographical Rewiew, 20(33), 161-188. DOI: 10.17295/dcd.71070. 